\title{
Occurrence of Downy Mildew \\ (Peronospora belbahrii) of Sweet \\ Basil (Ocimum basilicum L.) in Egypt
}

A.A. Hilal and Eman W. Ghebrial

Plant Pathol. Res, Inst., ARC, Giza, Egypt.

Qweet basil (Ocimum basilicum L., Fam. Lamiaceae) is an Simportant annual culinary herb crop used for both fresh and dry consumption and as a source of essential oil and oleoresin for manufacturing perfumes, food flavors and aromatherapy products and as ornamental and cut- flower plant.

Symptoms of downy mildew (Figs. 1A \& 1B and 2C) were recorded firstly during July, 2015 on basil plants (Ocimum basilicum L., Balady or local and Grand vertcvs) growing in some fields at Naser (Bani Adi), Beba (Safet-Rashin) and Somusta (Bedahel) counties, Beni- Suief Governorate, as yellowing of basil leaves of more than $60 \%$ of the growing plants. Small to large chlorotic lesions were found on more than $40 \%$ of plant leaves with necrotization from the middle, variable in diameter and the necrotic irregular spots are limited by the main veins. A grayish white furry growth was observed on the abaxial leaf surface. The fungus, however, was identified as Peronospora belbahrii Thines on the basis of morphological and microscopical characteristics. Sporangiophores (Fig. 2D) were hayline with a long of 396 to $806 \mu \mathrm{m}$ (averaged $583 \mu \mathrm{m}$ ), each had a straight trunk and monopodially branched 4 to 9 times (averaged 5.6). Sporangiophore ended with two curved acute branchlets. Olive to brown, rounded or ovoid sporangia were found to measure, on the average, $34.6 \mathrm{X} 27.0 \mu \mathrm{m}$. According to the available literatures, this is the first time to report this fungus and its disease in Egypt.
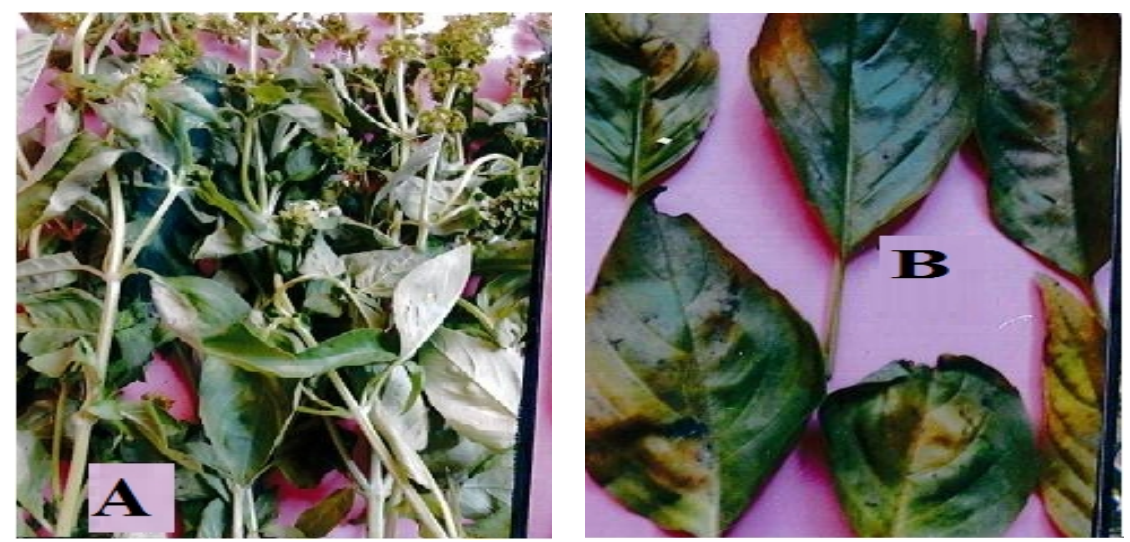

Fig. 1. Symptoms of downy mildew of basil on flowered plants (A) and on upper surfaces of the leaves $(B)$. 

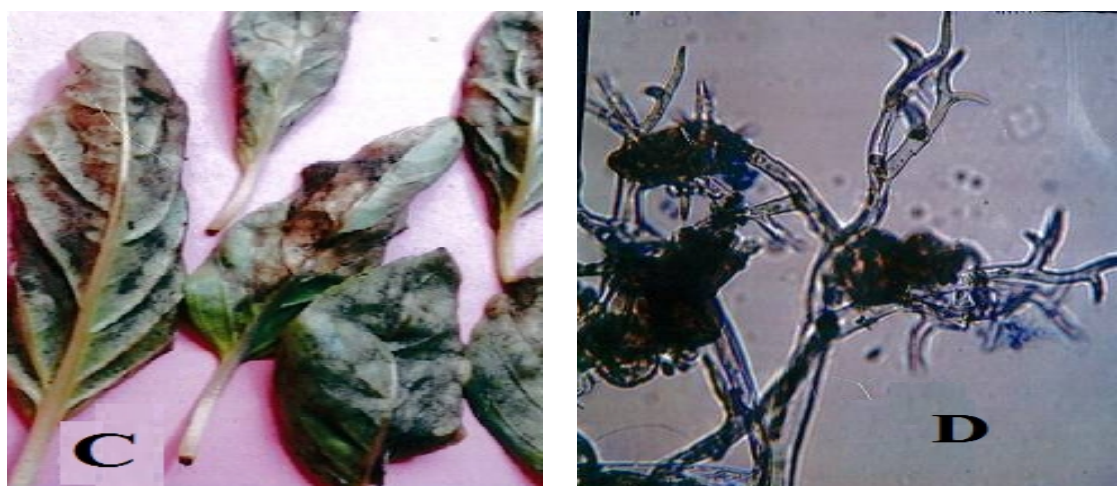

Fig. 2. Symptoms of downy mildew of basil on lower surfaces of the leaves (C) and (D) sporangiophores of Peronospora belbahrii (x500).

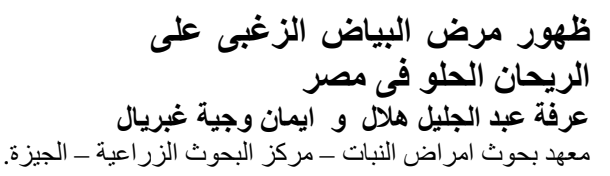

يعتبر الريحان الحلو محصول عشبى حولى هام للطبخ والاستخدام الطازج

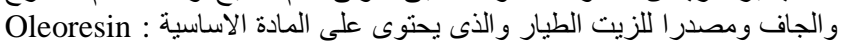

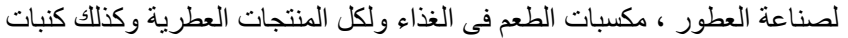

زينة ونبات أزهار قطف.

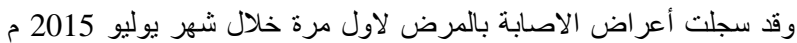

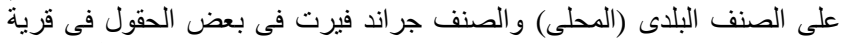

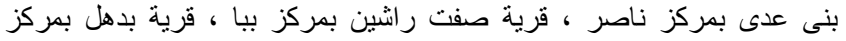

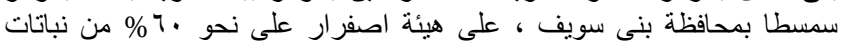

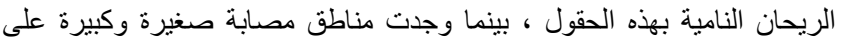

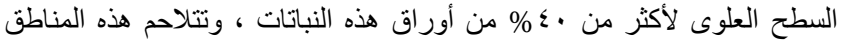

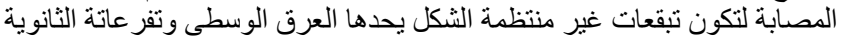

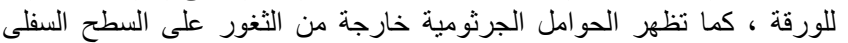

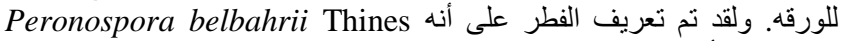

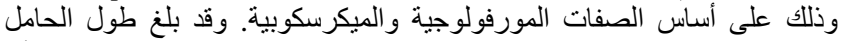

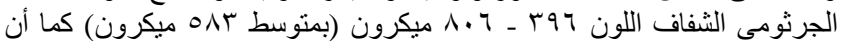

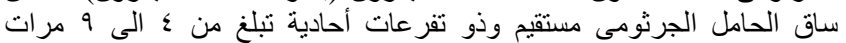

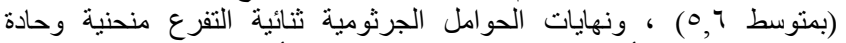

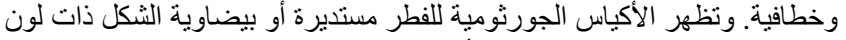

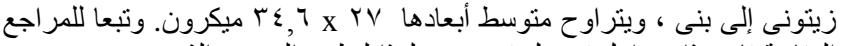

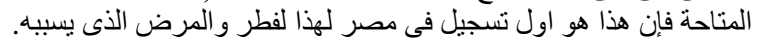

